ICPC and EFCC: Instruments of Selective Justice in Nigeria 
LWATI: A Journal of Contemporary Research, 7(1), 277-284, 2010

ISSN: $1813-2227$

UAS

\title{
ICPC and EFCC: Instruments of Selective Justice in Nigeria
}

\author{
S. O. Ajagun \\ E-Mail: Samolusholajagun@Yahoo.Com \\ Department of Public Administration \\ Faculty of Management Sciences \\ Ambrose Alli University, Ekpoma, Edo State - Nigeria
}

\begin{abstract}
This study is to examine ICPC and EFCC as instrument of selective justice in Nigeria. In generating data for the study, the survey technique was utilized. Based on the investigation of this study, it was revealed that selective pattern of the application of rules by the ICPC and EFCC undermines their effectiveness. Arising from the above revelation, the study recommended that the ICPC and EFCC should not be selective in the application of rules on the citizens, in their operations and activities in order to be very effective
\end{abstract}

\section{INTRODUCTION}

There are some unresolved problems in Nigeria, but the issue of corruption is troubling and the damage it has done to the polity is astronomical. The total breakdown of our value system has a direct impact on the pervading corruption in Nigeria. This fifty years old nation-state has gone through a lot over the years. From the first republic to the first military intervention in the state political apparatus to the bloody civil war six years after independence; to sit tight military interregnum in the political and economic realm which was far from stable?.

The menace of corruption leads to slow movement of files in offices, police extortion and slow traffic on the highways, port congestion, avoidable queues at passport office and gas stations, ghost workers syndrome, election irregularities, admission forgery among others. Some writers opine that corruption is endemic in all successive governments in Nigeria, and it is not peculiar to any region and ethnic group. It cut across faiths, religious dominations, and affect both young and old, man and woman alike. Consequently, it has defied all the necessary medicines (Olasupo, 2009:73). 


\section{Statement of the Problem}

Corruption is one of the major problems that bedeviled economic growth and development in Nigeria.

Every successive government have had anti-corruption policy to ensure its elimination or drastic reduction of the menace but unfortunately, government efforts have not yielded expected result. Against this back dropped, the researcher, decided to carry out this study to know the impact of the anti-corruption crusade in Nigeria (Ajagun, 2009:3).

\section{Objective of the Study}

The specific objective of the study is to examine the pattern of the application of rules, regulations, and laws by the Independent Corrupt Practices Commission and Economic and Financial Crimes Commission on the citizens in Nigeria.

\section{Conceptual Clarifications}

\section{Corruption}

Corruption is any action or commission enacted by a member of an organization, which is against the rules, regulations, norms, ethics, etc of the organization and the purpose of which is to meet the selfish end of the member (Azelama, 2002:16)

\section{ICPC}

The Independent Corrupt Practice and Other Related Offences Commission (ICPC) is an Anti-Graft Commission (Agency) established by the Federal Government of Nigeria under the Corrupt Practices and Other Related Offences Act 2000. the ICPC is saddled with the responsibility of fighting corruption and Other Related Offences. The responsibilities are: to receive, investigate acts of corruption and corrupt practices and to prosecute the offender(s).

\section{EFCC}

The Economics and Financial Crimes Commission (EFCC) is an Anti-Graft Commission established by the Federal Government of Nigeria under the Corrupt Practices and Other Related Offences Ant 2000. The Commission is vested with the responsibility of investigating and prosecuting offenders.

The Economic and Financial Crimes Commission (EFCC) (Establishment) Act 2004 was derived from the amended Act of Economic 


\section{S. O. Ajagun}

and Financial Crime (Establishment) Act 2002, with principal mandate to prevent, investigate and prosecute economic and financial crimes in Nigeria.

\section{METHODOLOGY}

\section{Research Design}

The research design adopted for this study is the descriptive survey method.

\section{Area of Study}

The area used for the study is Edo State Nigeria. The study covers 9 Local Government Areas in Edo State, Nigeria. These are: Akoko-Edo, Etsako West, Owan East, Esan West, Esan Central Igueben, Oredo, Orhionmwon and Ovia South West, with the following numbers of questionnaire received from Akoko-Edo 233, Etsako West 190, Owan East 186, Esan West 258, Esan Central 256, Igueben 256, Oredo 206, Orhionmwon 211, and Ovia South West 204.

\section{Population of the Study}

The population of the study includes: the government bureaucrats, Civil Servants, legislators, executives, officials of ICPC and EFCC and adults (people) in Edo State, Nigeria.

\section{Method of Sampling}

Specifically, simple random sampling was used to select twenty - seven (27)electoral wards from nine (9) simple randomly selected Local Government Areas out of the eighteen (18) Local Government Areas in the three (3) Senatorial Districts in Edo State, Nigeria

\section{Sample Size}

The sample size of 2000 respondents were used for the survey which was the statistical representation of Edo State with population of 1,603, 973 (N.P.C. 2006:8).

\section{Instrument}

The instrument for this study was constructed by the researcher. The survey (questionnaire) was structured into two sections. The first section of the instrument request respondents to give information on their personal data. Also, the second section was designed for respondents to respond to the 
questionnaire items and indicate their level of agreement. A four point LIKERT Scale was constructed ranging from strongly Agree (S.A), Agree (A), Disagree (D), Strongly Disagree (SD). The questions were structured in close-ended response format, which required the respondents to choose from four point's option.

\section{Validity}

The instrument used for the study was validated by experts in the field of Public Administration (Public Policy) both within and outside Ambrose Alli University, Ekpoma. All their inputs are corrections were effected.

\section{Reliability}

The questionnaire were tested for reliability by using the cronbach Alpha method to ensure that the questionnaire yielded consistent results when administered on the respondents, for this, thirty (30) individuals residing in areas not included in the final sample were administered the questionnaire and it yielded consistent results.

\section{Questionnaire Administration}

The researcher with five research assistants (aids administered the questionnaire to the respondents across Edo State. Two thousand, three hundred and twenty-two $(2,322)$ copies of the questionnaire were administered to respondents and two thousands questionnaire were returned. The return rate of $86.17 \%$ was sufficiently high to base analyses and draw logical conclusions (Ajagun, 2009:70).

\section{Data Analysis}

The data were analyzed using frequency and percentages.

\section{Scoring Procedure}

The 10 items of the questionnaire were subjected to frequency counts and percentages the items were scored on a four (4) point Likert scale of strongly Agree (4), Agree 3, Disagree 2, Strongly Disagree 1.

OResult

The data collected from the respondents were analyzed as shown in the tables below: 


\section{S. O. Ajagun}

Table 1: How would you describe the pattern of the application of anti-corruption policies in Nigeria?

\begin{tabular}{|c|c|c|c|c|c|}
\hline $\mathrm{S} / \mathrm{N}$ & Statement & & Respor & & \\
\hline 1 & $\begin{array}{l}\text { How would you describe the pattern of the application of anti- } \\
\text { corruption policies in Nigeria? }\end{array}$ & SA & A & $\mathrm{D}$ & SD \\
\hline i. & Unbiased & $\begin{array}{l}21 \\
(1.05)\end{array}$ & $\begin{array}{l}27 \\
(1.35)\end{array}$ & $\begin{array}{l}1720 \\
(86)\end{array}$ & $\begin{array}{l}232 \\
(11.6)\end{array}$ \\
\hline ii. & Selective & $\begin{array}{l}358 \\
(17.9)\end{array}$ & $\begin{array}{l}1200 \\
(60)\end{array}$ & $\begin{array}{l}342 \\
(17.1)\end{array}$ & $\begin{array}{l}100 \\
(5)\end{array}$ \\
\hline iii. & Ineffective & $\begin{array}{l}371 \\
(18.5)\end{array}$ & $\begin{array}{l}1087 \\
(54.3)\end{array}$ & $\begin{array}{l}320 \\
(16.0)\end{array}$ & $\begin{array}{l}222 \\
(11.1)\end{array}$ \\
\hline
\end{tabular}

Table 2: How would you describe the pattern of the application of the Anti-corruption policies in Nigeria?

\begin{tabular}{|c|c|c|c|c|c|}
\hline S/N & Statements & & Respon & & \\
\hline \multirow{3}{*}{$\begin{array}{l}\text { Question } \\
\text { 1(i) }\end{array}$} & & SA & $\mathrm{A}$ & D & SD \\
\hline & Unbiased & & & & \\
\hline & & 21 & $\begin{array}{l}27 \\
(1.35)\end{array}$ & $\begin{array}{l}1720 \\
(86)\end{array}$ & $\begin{array}{l}232 \\
(11.6)\end{array}$ \\
\hline
\end{tabular}

Source: Field Survey, 2009

Computation of Survey Frequency Percentage (\%)

Strongly Agree $=21 / 2000 \times 100=1.05 \%$

Agree $=27 / 2000 \times 100=1.35 \%$

Disagree $=1720 / 2000 \times 100=86 \%$

Strongly Disagree $=232 / 2000 \times 100=11.6 \%$

Total $=\mathbf{2 0 0 0}=\mathbf{1 0 0 . 0} \%$

Table 2 indicates the views expressed by various respondents across Edo State on the issue of anti-corruption policies agencies are unbiased in the application of its policies on Nigerian. This was the percentage of their responses 21 respondents representing $1.05 \%$ strongly agree, 27 respondents representing $1.35 \%$ agree, 1720 respondents representing $86 \%$ disagree, and 232 respondents representing $11.6 \%$ strongly agree.

Table 3: How would you describe the pattern of the application of the Anticorruption policies in Nigeria?

\begin{tabular}{llllll}
\hline S/N & Statements & \multicolumn{4}{c}{ Responses } \\
\hline & & SA & A & D & SD \\
Question & & & & & \\
1 (ii) & Selective & 358 & 1200 & 342 & 100 \\
& & $(17.9)$ & $(60)$ & $(17.1)$ & $(5)$
\end{tabular}

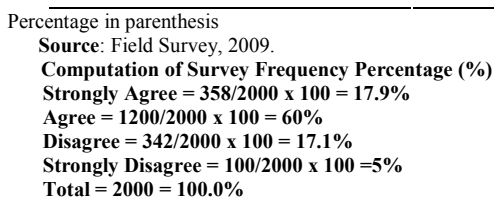


Table 3 shows the opinion expressed by respondents across the state of anticorruption policies (agencies) is selective in the pattern of application of anticorruption policies on Nigerians. This was the percentage of their responses: 358 respondents representing $17.9 \%$ were in strong agreement that the anticorruption policies agencies were selective in the application of the anticorruption policies on Nigerians, 1200 respondents representing $60 \%$ agree, 342 respondents representing $17.1 \%$ disagree that anti-corruption policies agencies were selective in dealing with Nigerians, 100 respondents representing $5 \%$ strongly disagree respectively.

Table 4: How would you describe the pattern of the application of the Anti-

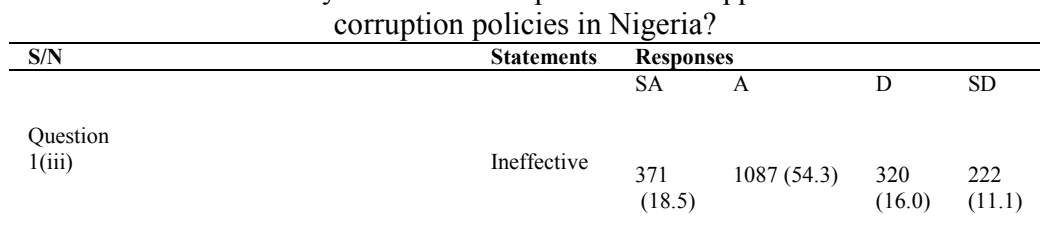

Percentage in parenthesis

Source: Field Survey, 2009.

Computation of Survey Frequency Percentage (\%)

Strongly Agree $=371 / 2000 \times 100=18.5 \%$

Agree $=1087 / 2000 \times 100=54.3 \%$

Disagree $=320 / 2000 \times 100=16.0 \%$

Strongly Disagree $=222 / 2000 \times 100=11.1 \%$

Total $=\mathbf{2 0 0 0}=\mathbf{1 0 0 . 0} \%$

Table 4 shows the range of percentage across the local government on the issue of the pattern of application of the anti-corruption policies is being ineffective. This was the percentage of their responses: 371 respondents representing $18.5 \%$ strongly agree, 1087 respondents representing $54.3 \%$ agree, 320 respondents representing $16.00 \%$ disagree, and 222 respondents representing $11.1 \%$ strongly disagree.

\section{DISCUSSION}

The implication of this is that majority of Nigerians were of the opinion that these anti-corruption policy agencies are selective in the application of rules/laws on the citizens. They are tools used in dealing with political opponents. This corroborate with media reports that the anti-corruption policy agencies, such as EFCC and ICPC are being used by Peoples Democratic Party (PDP) the party in power to oppress political opponents. There was a strong speculation that the EFCC play politics rather than pursuing the cases brought before it. For instance, the All Nigeria Peoples Party (ANPP) alleged that General Mohammed Marwa was arrested by the EFCC because he showed interest in contesting the presidential race with 


\section{S. O. Ajagun}

President Olusegun Obasanjo who was nursing the ambition for the third term (tenure) of office.

Also, the arrest of one time minister Alhaji Bashir Dalhatu, which people took as a vendetta against him because he was an in-law of former Head of State General Sani Abacha, while some politicians and their supporters reported that they were arrested and detained by EFCC because they failed to support the Obasanjo Third Term bid.

Furthermore, the case involving Senator Iyabo Obasanjo-Bello, 10 million Naira theft, belonging to Federal Ministry of Health was to buttress this fact in a media report: "EFCC begs court not to stop Iyabo's trial". This shows that despite the fact that former President Obasanjo's daughter was involved in acts of corrupt practices, some mechanisms were in place thwarting the efforts of the agency (EFCC) from probing the allegations, whereas many of such cases were arraign in the court for trials. Hence a media report: EFCC begs Court not to stop Iyabo Obasanjo-Bello's trial. (Ige, 2008).

In addition, a media reported that the United States Congressman has recanted former President Obasanjo (PDP) taped statement on how he planned to bribe the former Vice President Atiku Abubakar (AC) to facilitate a business deal (Jefferson bribe scandal), that he (Obasanjo) should have had the courage to apologised to Atiku, whom he did everything to malign over the fraudulent allegations (Lawal, 2008).

In this regard, Idemudia Omoifo remarked that:

Even when the government is trying to do what is right, they still find it hard to drop their anti-government mentality of the past. (Omoifo, 2006).

Finally, failure of anti-corruption policy agencies such as ICPC or EFCC to prosecute Senator Ibrahim Mantu, former Deputy Senate President who was alleged to be involved with series of acts of corrupt practices by influencing 105 plateau indigenes his home state into places of choice in Federal Government parastatals, such as NNPC, Warri Refining and PetroChemical Company, which was chaired by Jonah Jang. Hence, Saleh remarked that: Why is President Umaru Yar'Adua talking of rule of law, when he is shielding others who's are illegible to hold public office. (Saleh, 2008).

\section{RECOMMENDATIONS}

The study has revealed that the pattern of application of anti-corruption policies on citizens is selective. Based on the findings of the study recommendations are made:

(i) The Anti-graft agencies (ICPC and EFCC) should be allowed to function independently in the pursuits of their responsibilities

(ii) There should be no political interferences into the operations and activities of the anti-graft agencies. 


\section{CONCLUSION}

Therefore, selective pattern of the application of rules/laws only on the downtrodden people in the society, while the rich/elites walks freely with illgotten wealth negates the rule of law - that all citizens are equal before the laws of the land (Nigeria).

\section{REFERENCES}

Azelama, J.U. (2002). Public Enterprises Management in Nigeria

Benin-City: AMBIK Press

Egonmwan, J.A. (1993) Public Policy Analysis: Concept and Application Benin-City: S.M.O. Aka and Brothers Press.

EFCC Act, (2004). Economic and Financial Crimes Commission (EFCC) Establishment Act Abuja: Federal Government Press.

ICPC Act, (2000). The ICPC Act 2000 Abuja: Federal Government Press

NPC (2006) National Population Commission: Edo State Census Figures Abuja: Federal Government Press

Emeny onu, E. (2003). Accounting Profession, The Church and the Nigerian

State: Potent Change Agents for National Re-Birth Vanguard (Sunday) 19, July 22:33-34.

Ige, I.O. (2008). EFCC begs Court not to stop Iyabo Obasanjo-Bello's trial.Vanguard (Saturday) 13, June 14:7-15

Omoifo, I. (2006). Anti-Government Mentality. Vanguard 22, May 12:30.

Saleh, M. (2008). On Rule of Law.Vanguard 24, August 19:48.

Lawal, L. (2008). On the Marble.Newswatch 48(4) July 21:6.

Olasupo,M.A.(2009). "ICPC and the Challenges of Corruption and Indiscipline in Nigeria" Multidisciplinary Journal of Research Development,Vol. 12 No 2 August:1

Unpublished Thesis/Dissertation.

Ajagun, S.O. (2009) An Evaluation of Some Selected Anti-Corruption Policies In Nigeria: A Case Study of Edo State.

Unpublished Ph.D Thesis, Department of Public Administration, Faculty of Management Sciences, Ambrose Alli University, Ekpoma, Nigeria. 